\title{
Architecture_MPS
}

\section{Phantasmagoria and the Architecture of the Contemporary City}

Nadir Lahiji ${ }^{1}$

How to cite: Lahiji, N. 'Phantasmagoria and the Architecture of the Contemporary City.' Architecture_MPS, 2015, 7(1): 4, pp. 1-17. DOI:

https://doi.org/10.14324/111.444.amps.2015v7i4.001.

Published: 01 October 2015

\section{Peer Review:}

This article has been peer reviewed through the journal's standard Editorial double blind peer review.

\section{Copyright:}

(C) 2015, The Author(s). This is an Open Access article distributed under the terms of the Creative Commons Attribution License (CC-BY) 3.0 https://creativecommons.org/licenses/by/3.0/, which permits re-use, distribution and reproduction in any medium, provided the original author and source are credited • DOI: https://doi.org/10.14324/111.444.amps.2015v7i4.001

\section{Open Access:}

Architecture_MPS is a peer-reviewed open access journal. 


\title{
Title: Phantasmagoria and the Architecture of the Contemporary City ${ }^{1}$
}

\author{
Author: Nadir Lahiji
}

Architecture_media_politics_society. vol. 7, no. 4 .

October 2015

\section{Introduction}

In a provocative reversal of Guy Debord's aphorism in Society of the Spectacle, that "The spectacle is capital to such a degree of accumulation that it becomes an image," 2 Hal Foster writes that spectacle is "an image accumulated to the point where it becomes capital." 3 Foster's aphorism shifts attention onto the question of image and, in the context of architecture, served him as a vehicle to severely criticize the architecture of the spectacle, as most obviously represented by the work of Frank Gehry. ${ }^{4}$ In a reference to Adolf Loos's acerbic criticism of the Vienna Ringstrasse as a false "Potemkin village," 5 Foster sees Gehry's buildings exemplify what he calls "a computer-driven version of a Potemkin architecture of conjured surfaces." Later, in a seminal essay titled "Image Building," Foster picked up the same criticism of contemporary architecture within the framework of "accumulated image" that has become "capital" by tracing its origin to Pop art of the 1960s and the famous publication of Learning from Las Vegas in 1972 by Robert Venturi (with Denise Scott Brown and Steve Izenour). In this book Venturi and his collaborators criticized the absence of "symbolism" in modern architecture and made the fateful distinction between "the duck" or "formal expressionism," and "the decorated shed" or "applied symbolism."

Venturi opted for the latter in his theory and practice and the rest of story is well known, that is, the rise of postmodernism in late 1970s and 1980s architecture that got its main impetus from the argument in Venturi's book. Foster traces this distinction all the way up to our recent time and forcefully argues that a full-fledged case of this architecture of image-building in its most spectacular state is, again, Gehry designs which is at once a duck and decorated shed: the brand of "decorated duck." This brand is now a "whole flock" of buildings that "combine the willful monumentality of modern architecture with faux-populist iconicity of postmodern design." critique is not only directed at Gehry, it can be applied to all the buildings that come out of the new age of parametric designs and enter the global circle of image circulation: spectacular museums or art galleries, corporate 


\section{Amps}

headquarters, shopping centers etc. - whether they be designed by the stars of the moment or not. Indeed, going even further, it is arguable that this critique can, and should, be applied to companies, cities and even states who are seen as partaking in the image accumulation made possible by the "spectacle." The corporate entities and city authorities that seek to use this architecture for its image value wish, as Foster identifies, "to be perceived, through instant icons, as global players."

In this paper, the technological and capitalist urbanism produced by this contemporary condition will be referred to as the "hyper-mediated" city. It is a term that deliberately echoes that of Scott McQuire who calls this city the "Media City" and argues that it operates as a medium through which global capitalism and its spectacular imagery operate effectively. McQuire has analyzed the deterritorialization and dislocation of this city's spaces and buildings in much of twentieth century history and suggests that, despite its contemporary nature, it is still best analyzed through the work of Walter Benjamin. ${ }^{10}$ While McGuire does not explicitly reference Benjamin's notion of "Phantasmagoria" this paper suggests it is a notion of potentially fundamental importance to the analysis of today's hyper-mediated city, its digital architecture of spectacle and the underlying economic forces that shape it. It will suggest that the concept of Phantasmagoria that guided Benjamin in his inquiry into the configurations of the nineteenth century city - already a "media city" - has also an explanatory power to inform its transfiguration in the new economic and technological condition of our time.

However, an inquiry into the paradigms defining this city must deal not only with its architecture, its economic base and its technological organization that Benjamin traced in the changing nature of nineteenth century industrial city. It must also address the politico-aesthetic factors affecting the human sensorium and the structure of perception in the organization of experience that Benjamin, going back to the original Greek sense of term aesthetics, called aisthesis. It will be suggested that Hal Foster in his otherwise very perceptive analysis failed to address precisely this aspect of the image-spectacle affecting the contemporary human sensorium. Thus, more specifically, this paper will argue that the phantasmagoric images in the configuration of the hyper-mediated city, grounded as they are in the "new" technology, have not only altered our cities, but they have also altered the human sensorium and the mode of perception in the subject's experience in a way that is qualitatively different from the previous historical make-up that Benjamin discussed. In developing these arguments this paper will draw on the concept of anaesthetics, best analyzed by Susan Buck-Morss in relation to phantasmagoria in her seminal essay "Aesthetics and Anaesthetics: Walter Benjamin's Artwork Essay Reconsidered" and it will suggest that these ideas, alongside those of Foster may usefully be foregrounded as the conceptual category for a critique of the Phantasmagorias of "spectacle" - and our perception of them - in the technologically mediated city of today. ${ }^{11}$ 


\section{Amps}

\section{Phantasmagoria and the Industrial City}

Walter Benjamin began his 1939 Exposé, "Paris, Capital of the Nineteenth Century," by choosing the term "phantasmagoria" to guide his investigation into the economic and technological forms of organization of the city in the nineteenth century that would inform his Arcades Project. He wrote, "Our investigation proposes to show how, as a consequences of this reifying representation of civilization, the new forms of behavior and the new economically and technologically based creations that we owe to the nineteenth century enter the universe of phantasmagoria." 12

Benjamin used this term to define the "cultural values" specific to the commodity culture of urban industrial capitalism in the Paris of the nineteenth century. Rolf Tiedemann in his commentary on Benjamin relates the term to its specific Marxian usage, "Phantasmagoria: a Blendwerk, a deceptive image deigned to dazzle, is already the commodity itself, in which the exchange value or value-form hides the use-value. Phantasmagoria is the whole capitalist production process, which constitutes itself as a natural force against the people who carry it out."13

The term itself however, first originated in the 1802 to describe an exhibition of optical illusions produced by magic lanterns. As a new technology, it turns the appearance of reality into specters by tricking the senses through a technical manipulation. ${ }^{14}$ The term "phantasmagoria," as identified by Terry Castle, is defined as "a shifting series or succession of phantasm or imaginary figures, as seen in a dream or fevered condition, as called up by the imagination, or as created by literary description." 15 As Terry Castle points out, the original technical application of the word relates to the so-called "ghostshows of the late eighteenth-century and early nineteenth-century Europe - illusionistic exhibitions and public entertainments in which 'specters' were produced through the use of a magic lantern."

Margaret Cohen in her extended discussion of the term in her book on Walter Benjamin, Profane Illumination, traces the etymology of the word phantasmagoria to the etymology of allegory. As she notes, the word allegory originally means speaking other (allos) within the agora, public place. She explains that "[t]he etymology of allegory implying the possibility of redemption contrasts with the etymology of phantasmagoria, allegory's demonic doppelgänger. Constructed from phantasma and agoreuein instead of allos and agoreuein, allegory substitutes ghosts for the allos signifying allegory's transcendence." 16 Relating this etymological transformation to Benjamin's discussion of the nineteenth century cityscape, she notes that Benjamin's understanding of the nineteenth century commodity culture is one in which no escaping from the market place is possible: "It is a space where the transcendence of the authentically supernatural has turned to a demonic rooted in the process of market exchange."

Cohen notes how especially in the Arcades Project, Benjamin's interest in phantasmagoria as magic lantern is related to figuring the "nineteenth 


\section{Amps}

century's ideological projections" and to his treatment of the "technology of visual representation." She remarks that "Repeatedly, Benjamin evinces interest in the relation between a historical period's visual technology and its structures of understanding." 17 Among the basic mediating technical apparatuses of the nineteenth century city are stereoscopes, magic lanterns, panoramas, dioramas, myrioramas, georamas, mechanical spectacles, mirrors, photographs, advertisements, and cinematic projections. Universal exhibitions, arcades, train stations and department stores are the architectural spaces where the phantasmagorias of commodity culture are displayed.

These displays, in turn, transformed the human sensorium and its organization of perception, resulting in specific forms of modern subjectivity and alienation. Cohen writes that when "Marx describes the phantomlike objectivity of commodity fetishism as phantasmagorial, he characterizes an experience arising from the expansion of the commodity structure to all social relations, a process that reaches its apogee in industrial capitalism." 18 In origin then, the phantasmagoric was seen as both specular imagery produced through the "magic" of technology and/or illusion, and an integral component of the late industrial capitalism of the day.

\section{The State of the Phantasmagoric Today}

The media theorist and philosopher Norbert Bolz, in "Media Aesthetics: What is the Cost of Keeping Benjamin Current?" argues that Benjamin is actual only if grounded in the theory of modern media. ${ }^{19}$ This is posited despite the fact that Benjamin inaugurated an epistemic break in theories of human perception and within media theory for which Andreas Michel, who follows Bolz, has attempted to secure a founding place. He argues that Benjamin's writing (along with Carl Einstein's in the early twentieth century) brought an end to the philosophy of the subject grounded in its own self-consciousness, replacing Kant's "pure, original, unchanging consciousness" of transcendental apperception with a form of apperception "dependent upon a priori condition of media." ${ }^{20}$ For Bolz, this can be called the "historical apriority of the organization of sense perception" 21 whilst for Michel "human sensibility becomes, at least in part, a function of media - that is, a condition of bodily or technological apparatuses which restrict and enable access to the outside world." 22

In the context of this theory of media, Benjamin's achievement, or paradigm shift, was to conceive the "second nature" of machine technology in terms of "interplay" rather than "domination." According to Bolz this "presupposes a process that would include making the tremendous technical apparatus of our time into an object of human innervations." ${ }^{23}$ Elsewhere, Bolz asserts that the doctrine of perception "must nowadays be formulated as an aesthetics of media," in which the aesthetic is to be understood, as it was for Benjamin, in the original Greek sense of aisthesis. ${ }^{24}$

Considered in this multiple context, technology is directly connected to a media aesthetics that organizes the structure of perception. Moreover, since 


\section{Amps}

technology is irreducibly linked to the psychic apparatus of the modern subject, it always produces psychic traces, or rather specters. ${ }^{25} \mathrm{But}$, if technology generates its own illusions as necessary illusions, or to put it in a Kantian rather than a Nietzschian sense, transcendental illusions, which make up a collective and dream-like mode of perception, its effects are not always the same. In what can be defined as the first 'historical' stage of the media city, they are determined by the old new media of "technical reproducibility." In the contemporary condition of media technology prevailing in the last thirty years, they are the by-product (both loved and loathed by its critics) of what are called the new new media of "digital reproducibility." Both stages may be defined within the perceptual regime of capitalism's mode of exchange and commodity production that alters and continually reshapes the organization of the city, its buildings and perceptual experience itself.

However, as already indicated, Benjamin's notion of "Phantasmagoria" is not only of relevance today for the pointers it gives us regarding the nature of contemporary perception, it is of relevance for its linking of these issues with the socio-political-economic conditions of the age. In Das Capital Marx related the "secret" of the commodity to the way a "definite social relation" assumes the "phantasmagoric form of a relation between things." $26 \mathrm{He}$ wrote:

"The mysterious character of the commodity-form consists therefore simply in the fact that the commodity reflects the social characteristics of men's own labour as objective characteristics of the products of labour themselves, as the social-natural properties of these things. Hence it also reflects the social relation of the producers to the sum total of labour as a social relation between objects, a relation which exists apart from the outside of the producers." ${ }^{27}$

Further on Marx notes:

"It is nothing but the definite social relation between men themselves which assumes here, for them, the fantastic form [in original it is phantasmagorisch (phantasmagorical) of a relation between things." ${ }^{28}$

Benjamin adopted this concept but separated it from Marx's implicit connotation of it as "ideology critique." As Tiedemann points out, "Marx had in mind the circumstances of the bourgeois economy's 'necessarily false' consciousness, which is no less false for being necessary." 29 Tiedemann notes that "Benjamin's interest in culture was less for its ideology content, however, whose depth is unearthed in ideology critique, than for its surface or exterior, which is both promising and deceptive." 30 The symptom of the profound change in the apperception of architecture and the city for Benjamin, and today's "hyper-mediated" city and its computer generated spectacle architecture then, are not something occurring in isolation. On the contrary, they were, and are, intrinsically linked to the forms and and systems of commodification necessary in their respective forms of capitalism. 


\section{Amps}

\section{The Phantasmagoric and Hyper-Mediated Perception}

In her seminal essay "Aesthetics and Anaesthetics: Walter Benjamin's Artwork Essay Reconsidered" Susan Buck-Morss defines anaeasthetics as "the sensory experience of perception" and goes on to define a number of key aspects of the sensorial experience as of interest to Benjamin, and that of today. ${ }^{31}$ One major difference, appears to separate these two types of experience. In the nineteenth century the perception of the modern city, its movement, scales, congestion, activities and spectacles resulted in a sense of "shock" on the observer. However, the experience of the contemporary media city no longer manifests this element of "shock" operative in the metropolis which Benjamin traced and theorized in his analysis of Charles Baudelaire's allegorical poetry of the city. By contrast, the experience of the hyper-mediated city of today is conditioned by a generalized anaeasthetics in which caused by a form of defence mechanism instigated by the sensorial overload of "new" digital media technology and all its resultant urban stimuli - including its architecture of spectacle. What this results in is not a partial but a total breakdown of experience. Benjamin's notion of the modern experience as "Phantasmagoric" is, according to Buck-Morss, basically neurological and centered on shock. She argues that in the hyper-mediated city of today: "The cognitive system of synaesthetics has become, rather, one of anesthetics" and that "perception becomes experience only when it connects with sense-memories of the past." She also suggests that: "Without the depth of memory, experience is impoverished," and being "cheated out of experience" the synaesthetic system role has been reversed. Its goal today is to: "Numb the organism, to deaden the senses, to repress memory: the cognitive system of synaesthetics has become, rather that of anaesthetics [...] Thus the simultaneity of overstimulation and numbness is characteristic of the new synasethetic organization is anaesthetics." ${ }^{32}$ Elsewhere, she describes Phantasmagorias as "technoaesthetics." The perception that they provide are "real" and their impact upon the senses is "natural" from a neurophysical point of view. But what is important is their social function which she claims is a form of intoxication that becomes itself a social norm: "The goal is manipulation of the synaesthetic system by control of environmental stimuli. It has the effect of anaesthetizing the organism. Not through numbing, but through flooding the senses." Ultimately, "sensory addiction to a compensatory reality becomes a means of social control." ${ }^{33}$ Hence technology has a double function:

"On the one hand, it extends the human senses, increasing the acuity of perception, and forces the universe to open itself up to penetration by the human apparatus. On the other hand, precisely because this technological extension leaves the senses open to exposure, technology doubles back on the senses as protection in the form illusion, taking over the role of the ego in order to provide defensive insulation. The development of the machine as tool has its 


\section{Amps}

correlation in the development of the machine as armor ... It follows that synaesthetics system is not constant in history. It extends its scope, and it is through technology that this extension occurs." 34

Buck-Morss's reflections suggest that the contemporary hyper-mediated city represents the total breakdown of "experience" after the partial malfunction occasioned by "shock" that found its poetic expression in Baudelaire which Benjamin's ideas on "Phantasmagoria" are ideally placed to describe. It is thus a narcotic city, with a function similar to that of absinthe or hashish in the middle of nineteenth century. We, as subjects and the citizens of this narcotic city are technological addicts; our senses numbed and anaesthetized, victims of a system of political power and social control that maintains itself through the force of intoxication.

In its undifferentiated mode between reality and illusion, the "total environment" of the hyper-mediated city presents strong analogies with Richard Wagner's artistic attempts to produce "total environments" out of the work of art in his music dramas, which he conceived as a Gesamtkunstwerk. Theodor Adorno in his celebrated book In Search of Wagner, mindful of Benjamin's notion of phantasmagoria, analyzed Wagner's operas in conjunction with Marx's notion of commodity fetishism as phantasmagoria. Adorno wrote that in Wagner's work:

"The concept of illusion as the absolute reality of the unreal grows in importance: It sums up the unromantic side of phantasmagoria: Phantasmagoria as the point at which aesthetic appearance becomes a function of the character of the commodity. As commodity it purveys illusion." ${ }^{35}$

Adorno further criticized "the total environment" of Wagner's Gesamtkunswerk in the following terms:

"The unconscious, which Wagner learned about from Schopenhauer, has already become ideology for him: the task of music is to warm up the alienated and reified relations of men and make them sound as if they were still human. This technological hostility to consciousness is the very foundation of the music drama. It combines the arts in order to produce an intoxicating brew." 36

Buck-Morss in direct reference to Adorno adds, "Wagnerian music drama floods the senses and fuses them as a 'consoling phantasmagoria,' a 'permanent invitation to intoxication, as a form of oceanic regression."'37

The 'new architecture' of spectacle and the way it is experienced in the city of spectacles that is the hyper-mediated city functions in much the same way as Wagner's Gesamtkuntwerk. In a sense, it is the culmination of Wagner's project: it is the vehicle to provide an "aesthetic totality" and an "intoxicating brew." As Douglas Spencer has recently noted, the architecture of finance 


\section{Amps}

capitalism and mediated digital technology of the present, proposes nothing less than a "New Phantasmagoria." 38 Like Adorno criticizing Wagner's "occultation of production by means of the outward appearance of the product," Spencer shows convincingly that "today's architectural phantasmagorias are similarly invested in the "occultation of production." 39

Indeed, "much contemporary architecture," according to Spencer, "is aimed at the production of 'intoxicating brews' appealing to a sensuous realm of affectivity through environments and atmospheres that affirmatively mediate the smooth transitions, liberating flexibility and the vitalized mobility of global finance capital. Central to such tactics is a totalizing aesthetic in which the subject must be maintained in a state of full immersion, through an unbroken perceptual field of sensory experience, in which any inconsistencies or interruption that might break its affective spell are to be eliminated." 40

\section{Contemporary Digital Architecture, Cities and Mediated Experience}

In this new age of mass digital reproduction and an ever increasing overload of stimuli, the architecture that most characterizes the time has also become ever more "digitized." In recent decades the encroachment of the computer in architectural production and representation has reached new levels. Indeed, today's avant-garde are considered to be those who have made the 'digital turn' and see the very act of design as a form of computation process. Those who design these new digitized spectacles draw on multiple concepts from the cognitive sciences and biogenetics fields, including: the "complex and nonlinear," "morphogenesis," "animate and inanimate," "network," "blob," "fold," "fields," "fractal," "swarms," "informal," "self-organization," and last but not least, the more recent "Architectures non standard." ${ }^{1}$ "NonStandard' was derived from the field of mathematics and applies, according to its advocates, to all fields that employ algorithmic systems, with the expressed objective of radically altering the discipline by promoting the "generalization of singularity", leading to a new order in design. ${ }^{42}$

Yet, ironically, beyond all these seductive terminologies, the actual design of buildings according to this new mode boils down to the old-fashioned modernist dichotomy of "skin and bones," 43 with the exception that this formal strategy will yield a digitally warped object-building elevated to the status of an evocative-rapturous "illuminated sculpture." 44 Within this new conceptual framework, the figure of the architect is transmuted into that of a designer who occupies himself with designing luxury objects for wealthy clients. ${ }^{45}$ These architects cum designers now see themselves dealing with "datascapes," and the "flow of data." They focus, on "emotive styling," giving "shape to the flow of data," and "sculpting information." 46 Their work is a mainstay of cities who seek a global city skyline and status and thus, cities like Beijing seek to define themselves as images created by buildings such as the CCTV headquarters by Koolhaas/OMA and the Beijing Olympic 


\section{Amps}

Stadium/Bird's Nest by Herzog \& de Meuron. Bilbao creates an image for itself through the spectacle of Gehry's Guggenheim Museum, modern Los Angeles uses projects of the ilk of the Walt Disney Concert Hall, and cities like Zaragoza in Spain employ the imagery of buildings by the likes of Zaha Hadid and Santiago Calatrava.

All of this is grounded on "flexible accumulation" as the hegemonic mode of capitalist reproduction and consumption ${ }^{47}$ - a scenario characterized by cultural and entertainment centers, shopping malls, opera houses, museums and art centers, with their privatized public space. The reverse side of this architecture of exuberance is of course the "junk-space" that lies at the margins of many of our "hyper-mediated" cities and their star architect, digitally produced architectural objects. Within this condition, the culture of design has paradoxically revived the cult of the aura in the art-objects, and by extension, in the architectural object as well, with a new set of special visual effects. ${ }^{48}$ Yet, despite this aura most, if not all of these spectacle buildings, are seen as images and experienced as such. They enter into the circuits of capital accumulation as star buildings that promote a city or a company. They are seen on pages of magazines, the advertising hoardings of billboards, the adverts that appear on screens of all sorts - from television screens in the home to promotional electronic hoardings in airports and on hand held electronic devices of all sorts.

However, when placed in the physical context of the modern city they can still operate as images - as media. They can be the frames of advertising hoardings, they are still photographed by tourists, filmed by television crews, registered and entered as data on mobile phone apps and used as reference points in hand held navigation devices etc. The city dweller is, in the modern world, ever more prone to experiencing architecture as and through media. If one considers the most highly mediated centers of our cities - the electronic-architectural bazars of urban points such as Times Square, New York, Leicester Square, London, or the Shibuya Crossroads in Tokyo, what results from this very literal application and multiplication of architecture as media is that the sensorial experience of the modern city visiting subject reaches such a pitch that Susan Buck-Morss's anesthetization becomes the only recourse one has. In these centers of media cities, in which the digitally produced spectacles of spectacular architecture collide in the creation of the intoxicating Gesamtkuntwerk of commercialized architecture, the result is a form of "urban trash" characterizing a modern experience that one can only respond to through cerebral numbness or its opposite - as the proponents of this architecture and city experience would suggest - full acceptance and immersion.

With full immersion in the so-called "digital age," we have effectively moved from a discourse network ${ }^{49}$ based on the "mechanical reproduction" to the discourse network that has been celebrated as the age of "digital reproduction." This move, in essence, stems from the discourse networks characterizing both Modernist culture and more contemporary 


\section{Amps}

postmodernism. In both of these discourse networks media technologies play the central role and both readings are based on the discourse of capitalism, changing from its monopoly to its global stage, and politically its transformation of liberalism and its "autonomous individual" to the neoliberalism that comes with its specific mode of subjectivity and perception. It is a transformation in these terms that can be effectively interpreted through Benjamin's notion of the phantasmagoria and which makes it ideal for understanding both the causes and the consequences of the hypermediated city experience of today.

\section{The Actuality of Benjamin and the Modern Experience}

In suggesting that Benjamin's concept of Phantasmagoria developed in the context of the nineteenth century remains an ideal framework through which to understand contemporary architecture, urbanism and the mediated nature of how these disciplines have come to operate and be experienced in the context of developed capitalism, this paper has traced out Benjamin's arguments through a range of channels. It has returned to his premise that underlying force in the changes to perception instigated by the industrial city of his day was the economic structure of the financial system of the period. Suggesting that these conditions have continued to develop, have amplified and intensified in the intervening century the paper examined those theorist who have sought to keep Benjamin current and who have adapted new ideas that stem from some of his writings. Most notably we looked at Susan BuckMorss and Hal Foster, both of whom can be seen as indispensable in a consideration - through Benjamin - of the hyper-mediated environments that are the iconic media(ted) centers of contemporary city spectacles such as Times Square in New York, Leicester Square in London and any of the spectacle buildings found there and elsewhere.

In examining these theorists and the architecture and city experiences that result from an application of their ideas to the contemporary city, we come to a conclusion in which the modern perceptual condition can be defined as one of anaesthesia; that the underlying forces behind this are primarily economic; and that the modern urban condition and architecture that result from this can arguably be defined as the "trash of spectacle." However, in making these conclusions, a note of defiance can be struck. Despite the best efforts of the proponents of the increased digitalization architecture, urbanism and experience we have mentioned here, the aesthetic totalization of architectural style and experience in its current digital form that results within the hyper-mediated city may be interpreted as "destined to fail." The two principal reasons for this can be discerned again in Benjamin's reading of "Phantasmagoria": the discomfort produced by a mode of perception that obliges us to reconfigure how we see, perceive and experience; and the inherent contradictions of the underlying capitalist system which produces architecture and cities of ever more spectacle. 


\section{Amps}

If we consider the first of these reasons, the fundamentally altered mode of perception that arguably characterizes our times, the hedonistic and narcissistic "subject" in this system is permanently in thrall to new "virtual" technologies that produce the architecture of the city - and through which we increasingly experience it. As a result, numerous consequences are likely to emerge including the border between what is "reality" and what is the real being obliterated - a scenario that leaves the subject ever more unable to differentiate reality from virtuality and thus vulnerable to a condition of psychosis. It is a state of confusion and disorientation that cannot persist indefinitely and a state that will leave us longing for material engagement and "real" experience. In addition however, this confusion is accompanied by, amongst other things, what Susan Buck-Morss is a state of anaesthesia. Thus, what we end up with potentially is a complete breakdown of our experience itself that potentially induces a form of alienation.

If we turn to the second reason, the economic/political, we are obliged to identify that all this has its roots in the economic and techno-cultural forces of a global digital capitalism. As identified by the standard Marxist interpretation of this economic system, the competitive drive to sell more leads to the incessant drive to produce more things more quickly - each one by necessity intended to supersede the product it must replace in order to be "bought and sold itself." As such, this system, achieves little more than the continual production of architectural spectacles - each successive spectacle destined to be replaced and outmoded almost instantly. The nature of capitalism itself then, will consign this architecture to the past before it has time to take root. This, we would suggest, is intrinsically linked to the poor quality of architecture that results.

In understanding this through the prism of Benjamin, we are of course drawing primarily on the concept of the Phantasmagoria. However, the quality, or lack thereof, in the architecture of our contemporary cities also invokes Benjamin's statements on Angelus Nouvus. In his much cited thesis IX "On the Concept of History," Benjamin wrote:

"There is a picture by Klee called Angelus Nouvus. It shows an angel who seems about to move away from something he stares at. His eyes are wide, his mouth is open, his wings are spread. This is how the angel of history must look. His face is turned towards the past. Where a chain of events appears before $u s$, he sees one single catastrophe, which keeps piling wreckages upon wreckage and hurls it at his feet. The angel would like to stay, awaken the dead, and make whole what has been smashed. But a storm is blowing from Paradise and has got caught in his wings; it is so strong that the angel can no longer close them. This storm drives him irresistibly into the future, to which his back is turned, while the pile of debris before him grows toward the sky. What we call progress in this storm." 50

The wind of "progress" that today's avant-garde and commercialized city spectacles call into service could not be better portrayed but by Benjamin's 


\section{Amps}

thesis. So, when we return to Benjamin in the context dealt with in this paper, we are not only presented with an ideal framework through which to understand the contemporary subject - as anaesthetized in the face of the modern city spectacle, its digital imagery, computer generated architecture and its commercially saturated images - we are presented with a framework through which to consider the nature of avant-garde progress in the digital age. Benjamin's evocative description of the "angel of history" could also not be more telling of the prevailing zeitgeist, and a backward glance over the short history of the phantasmagoria of the mediatized architecture and urbanism of the last three decades reveals, just as it did for Benjamin's angel, the debris of progress. Only for us, this debris is epitomized ever more as media, through media and produced in mediated ways.

\section{Notes}

1 The argument in this essay is a short version of an extended analysis which is forthcoming in the co-authored book with Libero Andreotti, The Architecture of the Hyper-Mediated City: Phantasmagoria (New York: Routledge, 2015).

2 Guy Debord, The Society of Spectacle (Detroit: Black \& Red, 1983), no pagination.

3 Hal Foster, "Master Builder," in Design and Crime and Other Diatribes (London and New York: Verso, 2002), 41.

4 However, this critique has wider ranging targets which also see architects such as Rem Koolhaas being part of this cult of image-building - his CCTV building in Beijing, or his Library in Seattle, being clear examples.

5 Potemkin Village in this context refers to Grigory Potemkin and the construction of a false settlement along the Dnieper River in the Crimea, constructed to deceive Empress Catherine II in 1787. Adolf Loos used it in his an essay of 1898 to criticize Vienna. Anthony Vidler, "Introduction," in Architecture between Spectacle and Use (Williamsburg: Sterling and Francine Clark Art Institute, 2008).

6 Hal Foster, "Image Building," in Architecture between Space and Use (Williamsburg: Sterling and Francine Clark Art Institute, 2008), 38.

7 Ibid., 175.

8 Foster's analysis offers a novel criticism of the "spectacle" (in Debord's sense of the term) of contemporary architecture and its role on a larger socio-political canvas. However, he stops short of extending his criticism of "image building" to the spectacle of the contemporary city and its configuration grounded in technological media and contemporary digital capitalism. He consequently, does not follow through the implications of his own thinking to the full.

9 Nadir Lahiji and Libero Andreotti, The Architecture of the Hyper-Mediated City: Phantasmagoria (New York: Routledge, 2016).

10 Scott McQuire, The Media City: Media, Architecture and Urban Space (Los Angeles: Sage, 2008), 20. McQuire starts his analysis by a reference to Friedrich Kittler, the prominent late German media theorist who, in his seminal "The City as a Medium," argued that the city has always been a medium. See also Freidrick 


\section{Amps}

Kitller, "The City Is a Medium," in New Literary Theory, vol. 27, no. 4, (Autumn, 1996).

11 Susan Buck-Morss, “Aesthetics and Anaesthetics: Walter Benjamin's Artwork essay Reconsidered," in October, 62 (Autumn, 1992).

12 Walter Benjamin, "Paris, Capital of the Nineteenth Century, Expose of 1939" in The Arcades Project, trans. Howard Eiland and Kevin McLaughlin (Cambridge, MA: The Belknap Press of Harvard University Press, 1999), 14.

13 Rolf Tiedemann, "Dialectics at a Standstill, Approaches to the Passagen-Werk," in Walter Benjamin The Arcades Project, trans. Howard Eiland and Kevin McLaughlin (Cambridge, MA: The Belknap Press of Harvard University Press, 1999), 938.

14 Margaret Cohen, Profane Illumination, Walter Benjamin and the Paris of Surrealist Revolution (Berkeley: University of California Press, 1993). Cohen informs us, the phantasmagoria was invented in the late 1790s by EtienneGaspard Robertson. See alsoTerry Castle, "Phantasmagoria: Spectral Technology and the metaphoric of Modern Reverie," in Critical Inquiry, 15 (Autumn, 1988).

15 The Oxford English Dictionary definition quoted by Castle in "Phantasmagoria: Spectral Technology and the metaphoric of Modern Reverie," Critical Inquiry, 15 (Autumn, 1988), 27.

16 Margaret Cohen, Profane Illumination, 236.

17 Ibid., 238.

18 Ibid., 245.

19 Norbert Bolz, "Aesthetics of Media: What is the Cost of Keeping Benjamin Current?" in Mapping Benjamin: The Work of Art in the Digital Age, Hans Ulrich Gumbrecht and Michael Marrinan (Stanford: Stanford University Press, 2003). Note that he uses the same Benjaminian concept, the German Aktuell or Aktualität, which is inadequately translated as "current." For a discussion of Benjamin's concept of Aktualität see Sigrid Weigel, Body-and Image-Space, Re-reading Walter Benjamin (London: Routledge, 1996).

20 Andreas Michel, "Media Theory: On the Legacy of the Avant-Gardes in Carl Einstein and Walter Benjamin," in South Atlantic Quarterly 96, no. 4 (Fall 1997): 730 .

21 Michel, "Media Theory," 730.

22 Michel further offers an instructive shorthand definition of media: "The term medium/media thus refers here to either human or technological apparatuses that shape human sensibility (sinnlichkeit) and without which it would be impossible to conceive of the production of knowledge." Ibid, 731.

23 Bolz, "Aesthetics of Media," 26.

24 Norbert Bolz and Willem van Reijen, Walter Benjamin (New Jersey: Humanities Press, 1996). See also Nadir Lahiji, "Architecture under the Gaze of Photography: Benjamin's Actuality and Consequences," Architectural Theory Review 10, no. 1, 2005.

25 Jacques Derrida, "Freud and the Scene of Writing," in Writing and Difference, trans., with an introduction by Alan Bass (Chicago: The University of Chicago 


\section{Amps}

Press, 1978). See also Jacques Derrida, The Specters of Marx, The State of the Debt, the Work of Mourning, and the New International, trans. Peggy Kamuf (New York: Routledge, 1944) and Nadir Lahiji, Architecture under the Gaze.

26 Tiedemann, "Dialectics at a Standstill."

27 Karl Marx, Capital, Volume 1 (London: Penguin Classics, 1990), 164.

28 Ibid., 165.

29 Tiedemann, "Dialectics at a Standstill," ibid., 938.

30 Ibid.

31 Buck-Morss, "Aesthetics and Anaesthetics," 6. See also Karlheinz Barck, "Connecting Benjamin: The Aesthetic Approach to Technology," in Mapping Benjamin, The Work of Art in the Age of Digital Technology, eds., Hans Ulrich Gumbrecht and Michael Marrinan (Stanford: Stamford University Press, 2003).

32 Buck-Morss, "Aesthetics and Anaesthetics," 16-18. In regard to specific definition of the concept of "synaesthesia" Buck-Morss writes that "The field of the sensory circuit thus corresponds to that of 'experience,' in the classical philosophical sense of mediation of subject and object, and yet its very composition makes the so-called split between subject and object (which was the constant plague of classical philosophy). In order to differentiate our description from the more limited, traditional conception of the human nervous system which artificially isolates human biology from its environment, we will call this aesthetic system of sense-consciousness, decentered from the classical subject, wherein external senseperception come together with the internal images of memory and anticipation, the 'synaesthetic' system." Ibid., 13.

33 Ibid., 22-23.

34 Ibid., 22.

35 Theodor Adorno, In Search of Wagner, trans. Rodney Livingston (London. New York: Verso, 2005), 79.

36 Ibid., 89

37 Buck-Morss, "Aesthetics and Anaesthetics," 24.

38 Douglas Spencer, "The New Phantasmagoria: Transcoding the Violence of Financial Capitalism," in Nadir Lahiji, ed., The Missed Encounter of Radical Philosophy with Architecture (London: Bloomsbury, 2004).

39 Ibid., 88.

40 Ibid., 89-90. See the more elaboration of this point in Spencer's comprehensive discussion of contemporary architecture that I have abbreviated here for the lack of enough space.

41 This was the title of an exhibition held at the Centre Pompidou in 2003: Architecture non standard, Centre Georges Pompidou, Paris, December 2003-March 2004. See the catalogue by Frédéric Migayrou and Zeynep Mennan, eds., Architectures non standard (Paris: Editions du Center Pompidou, 2003). It was publicized by Mario Carpo as the "latest avatar to date of the digital revolution in architecture."

42 See the definition of "non-standard architectures" [http: //www.centrepompid ou.fr]

43 Anthony Vidler, "Skin and bones," in Warped Space, Art, Architecture, and Anxiety in Modern Culture (Cambridge: The MIT Press, 2000). 


\section{Amps}

44 This will leave innocent observers in the state of "anaesthetics," as "hallucinating fools" effectively removed from any possibility of contestation. They will be in a condition of political inaptitude as the obverse side of the so-called digital aptitude.

45 Foster, "A Little Dictionary of Received Ideas about Contemporary Design," a lecture delivered at the conference in Paris in 2007 on "Walter Benjamin and Architecture," and subsequently printed in French in Speilraum: W. Benjamin et L'Architecture, ed., Libero Andreotti (Paris: Editions La Villette, 2011), 337.

46 Quoted in Foster, "A Little Dictionary of Received Ideas about Contemporary Design," ibid. Also see Hal Foster's Design and Crime (and Other Diatribes) (London: Verso, 2002).

47 Lutz Koepnick, "Aura Reconsidered: Benjamin and Contemporary Visual Culture," in Benjamin's Ghosts, Interpretations in Contemporary Literary and Cultural Theory (Stanford: Stanford University Press, 2002). Lutz writes: "PostFordist culture, by way of contrast, is characterized by the workings of hybrid multimedia aggregates and diversified and hardly ever consistent identities... PostFordist techno-culture grafts the principle flexible accumulation onto the exchange and acquisitions of symbolic materials. In doing so, it nullifies what allowed the individual to experience Fordist consumer societies as imagined communities. Cultural technologies such as VCRs or Walkmans, fast-forward buttons or digital cameras, discharge the assumptions about homogeneous time and space so central to the ideological effects of Fordist mass media," 108.

48 As Foster put it: "Might this 'design subject' of consumerism be the unintended offspring of the 'constructed subject' of postmodernism? One thing seems clear: contemporary design abets a near-perfect circuit of production and consumption."

"A Little Dictionary," ibid., 337.

49 The term "Discourse Network" is a vast concept that we have adopted after Friedrich A. Kittler. He defines the term as "the network of technologies and institutions that that allow a given culture to select, store, and produce relevant data." Friedrich A. Kittler, Discourse Network, 1800/1900, trans. Michael Metteer with Chris Cullens, (Stanford: Stanford University Press, 1990), 369. Kittler's term has some affinities with Michel Foucault's "Discourse Analysis" to link power and knowledge, but goes beyond it to cover the concept of contemporary media technologies. The term is very extensive and attempts to link physical, technological, discursive, and social systems. See also Friedrich A. Kittler Gramophone, Film, Typewriter, trans. Geoffrey Winthrop-Young and Michael Wutz (Stanford: Stanford University Press, 1999).

50 Walter Benjamin, "On the Concept of History," in Walter Benjamin, Selected Writings, volume 4, 1938-1940 (Cambridge, MA: The Belknap Press of Harvard University Press, 2003), 392.

\section{Bibliography}

Andreas Huyssen, "Baudlirard's Theory of Simulation." In Twilight Memories, Marking Time in a Culture of Amnesia. New York and London: Routledge, 1995. 


\section{Amps}

Andreas Michel, "Media Theory: On the Legacy of the Avant-Gardes in Carl Einstein and Walter Benjamin.” South Atlantic Quarterly 96, no. 4 (Fall 1997).

Douglas Spencer, "The New Phantasmagoria: Transcoding the Violence of Financial Capitalism." In Nadir Lahiji, ed., The Missed Encounter of Radical Philosophy with Architecture. London: Bloomsbury, 2004.

Guy Debord, The Society of Spectacle. Detroit: Black \& Red, 1983. No pagination.

Hal Foster, "Master Builder," in Design and Crime and Other Diatribes. London and New York: Verso, 2002.

Jacques Derrida, "Freud and the Scene of Writing." In Writing and Difference, trans., with an introduction by Alan Bass. Chicago: The University of Chicago Press, 1978.

Jacques Derrida, The Specters of Marx, The State of the Debt, the Work of Mourning, and the New International, trans., Peggy Kamuf. New York and London: Routledge, 1944.

John Fekete, The Critical Twilight. London: Routledge \& Paul Kegan, 1977.

Karlheinz Barck, "Connecting Benjamin: The Aesthetic Approach to Technology." In Mapping Benjamin, The Work of Art in the Age of Digital Technology, eds., Hans Ulrich Gumbrecht and Michael Marrinan. Stanford: Stanford University Press, 2003.

Lutz Koepnick, “Aura Reconsidered: Benjamin and Contemporary Visual Culture." In Benjamin's Ghosts, Interpretations in Contemporary Literary and Cultural Theory. Stanford: Stanford University Press, 2002.

Margaret Cohen, Profane Illumination, Walter Benjamin and the Paris of Surrealist Revolution. Berkeley: University of California Press, 1993.

Mariam Hensen, "Benjamin and Cinema: Not a One-Way Street." In Benjamin's Ghosts: Interventions in Contemporary Literary and Cultural Theory, ed. Gerhard Richter. Stanford: Stanford University Press, 2002.

Nadir Lahiji and Libero Andreotti, The Architecture of the Hyper-Mediated City: Phantasmagoria (New York: Routledge, 2015).

Nadir Lahiji, "Architecture under the Gaze of Photography: Benjamin's Actuality and Consequences." In Architectural Theory Review (Journal of the Faculty of Architecture, University of Sidney), 10, no. 1 (2005).

Norbert Bolz and Willem van Reijen, Walter Benjamin. New Jersey: Humanities Press, 1996.

Norbert Bolz, "Aesthetics of Media: What is the Cost of Keeping Benjamin Current?" In Mapping Benjamin: The Work of Art in the Digital Age, eds., Hans Ulrich Gumbrecht and Michael Marrinan. Stanford: Stanford University Press, 2003.

Rolf Tiedemann, "Dialectics at a Standstill, Approaches to the Passagen-Werk," in Walter Benjamin's The Arcades Project. In Walter Benjamin, trans. Howard Eiland and Kevin McLaughlin. The Belknap Press of Harvard University Press, Cambridge, MA, and London, 1999.

Scott McQuire, The Media City: Media, Architecture and Urban Space. Los Angeles: Sage, 2008.

Sigrid Weigel, Body- and Image-Space, Re-reading Walter Benjamin. London: Routledge, 1996. 


\section{Amps}

Susan Buck-Morss, "Aesthetics and Anaesthetics: Walter Benjamin's Artwork essay Reconsidered.” October 62 (Autumn 1992).

Terry Castle, "Phantasmagoria: Spectral Technology and the metaphoric of Modern Reverie." Critical Inquiry 15 (Autumn 1988).

Theodor Adorno, In Search of Wagner, with a New forword by Slavoj Zizek, trans., Rodney Livingston. London. New York: Verso, 2005.

Walter Benjamin, "Paris, Capital of the Nineteenth Century, Expose of 1939." In The Arcades Project, trans. Howard Eiland and Kevin McLaughlin (Cambridge, MA: The Belknap Press of Harvard University Press), 1999.

"On the Concept of History," in Walter Benjamin, Selected Writings, volume 4, 1938-1940 (Cambridge, MA: The Belknap Press of Harvard University Press, 2003), 